\title{
Binding of Aspergillus fumigatus spores to lung epithelial cells and basement membrane proteins: relevance to the asthmatic lung
}

\author{
Isabel M J Bromley, Kenneth Donaldson
}

\begin{abstract}
Background-Aspergillus fumigatus is an opportunistic pathogen to which asthmatic subjects are particularly susceptible. The ability of spores of $A$ fumigatus to bind to pulmonary cells and basement membrane proteins was investigated to determine the mechanisms involved in this susceptibility.

Methods - Cells of the A549 pulmonary epithelial cell line or purified basement membrane proteins were immobilised on the wells of microtitre plates. They were then exposed to spores of $A$ fumigatus in suspension, with or without various pretreatments of the spores, cells, and proteins. Adherent spores were counted by light microscopy.

Results - Spores of $A$ fumigatus bound in a concentration dependent manner to A549 epithelial cells and pretreatment of cells with interferon $\gamma(2500$ units $/ \mathrm{ml})$ caused a significant doubling of spore binding. Binding of spores to A549 cells was inhibited by about a third by preincubation of the spores with fibrinogen $(100 \mu \mathrm{g} / \mathrm{ml})$. Spores bound specifically to extracellular matrix (ECM) components laid down by A549 cells, and pretreatment of the ECM components with hydrogen peroxide $(25-80 \mu M)$ enhanced spore binding by approximately one third. They also bound specifically and in a saturable manner to purified fibrinogen, fibronectin, laminin, type I collagen, and type IV collagen. Pre-incubation of spores with Arg-Gly-Asp tripeptide (RGD; 50-200 $\mu \mathrm{g} /$ $\mathrm{ml}$ ) inhibited binding to fibronectin and type I collagen by $50 \%$.

Conclusions - This study suggests that the presence of activated epithelial cells and the exposure of basement membrane that occurs in asthma, together with oxidant stress, may facilitate the colonisation of the asthmatic lung by $A$ fumigatus. The RGD sequence may be involved in spore binding to some ECM proteins. Free fibrinogen may protect against binding of $A$ fumigatus spores to the pulmonary epithelium.

(Thorax 1996;51:1203-1209)
\end{abstract}

Keywords: Aspergillus fumigatus, spores, asthmatic lung.

Correspondence to:
Professor K Donaldson

Received 29 March 1996 Returned to authors

30 May 1996

Revised version received

20 June 1996

20 June 1996 Accepted for publication

Accepted for
Aspergillus fumigatus is an ubiquitous saprophytic fungus with spores of a respirable size
$(3 \mu \mathrm{m})$ that are easily dispersed. ${ }^{12}$ A high incidence of $A$ fumigatus spores has been noted in human lungs at post-mortem examination relative to other spores of a similar size, ${ }^{3}$ suggesting that it is able to persist in the lung. In favourable circumstances the spores can establish an infection and/or cause an allergic reaction. ${ }^{2}$ Allergic bronchopulmonary aspergillosis is a disease that predominantly affects asthmatic patients. It is caused by a hypersensitivity response to germinating $A$ fumigatus in the lung and can be serious and even fatal. ${ }^{4}$

The asthmatic lung appears to be particularly susceptible to $A$ fumigatus spores and several studies have reported high rates of sensitivity to A fumigatus in asthmatic subjects. In one study $16 \%$ of extrinsic asthmatic subjects reacted to $A$ fumigatus. ${ }^{5}$ In another study of 2080 patients with chest disorders $7 \%$ had $A$ fumigatus in their sputum, of which asthma was the predominant disorder compared with bronchitis, bronchiectasis, or pneumonia. ${ }^{6}$ This shows that $A$ fumigatus is present more frequently in asthmatic patients than in those with other respiratory diseases, suggesting that asthmatic airways present a favourable environment to fungal growth which would enhance the likelihood of spore proteins gaining access to immune cells in the interstitium, leading to sensitisation. The same study also reported that $24 \%$ of asthmatic patients had positive skin prick tests to Aspergillus species.

Deposited spores will inevitably come into contact with the pulmonary epithelium, but little is known of the factors involved in this interaction. We have investigated the binding of $A$ fumigatus spores in experimental conditions that mimic the asthmatic lung - that is, binding to activated pulmonary epithelial cells, basement membrane components, and fibrinogen under conditions of oxidant stress using the lung type II epithelial cell line A549 as a model air space epithelial cell.

\section{Methods}

SPORES OF ASPERGILLUS FUMIGATUS

A clinical isolate of Aspergillus fumigatus (obtained from Dr Leslie Milne, Department of Mycology, Western General Hospital, Edinburgh) was cultured at $30^{\circ} \mathrm{C}$ on malt agar. Ten day old spores were harvested by tapping the plates on a surface and by collection into a homogeniser with a spatula. Spores were added to phosphate buffered saline (PBS) $\mathrm{pH} 7.4$ (Gibco, UK), homogenised for two minutes, and then dispersed in a sonic bath for three 
minutes to wet the spores and to prevent clumping. The spores were then counted in an Improved Neubauer chamber and a suspension was made up in PBS pH 7.4 at a concentration of $10^{6}-10^{7}$ spores $/ \mathrm{ml}$.

\section{CELLS IN CULTURE}

Monolayers of the A549 lung epithelial cell line (ECACC) were cultured in Dulbecco's modified Eagle's medium (DMEM; Gibco, UK) supplemented with penicillin (Sigma Chemical Co, UK; 50000 units/1), streptomycin (Sigma; $50 \mathrm{mg} / \mathrm{l}$ ) and fetal calf serum (Sigma; $10 \% \mathrm{v} / \mathrm{v}$ ); this is called complete DMEM (CDMEM). Cells were cultured at $37^{\circ} \mathrm{C}$ in an atmosphere of $5 \%$ carbon dioxide in air, harvested just before confluence using trypsin with $0.05 \%(\mathrm{w} / \mathrm{v})$ ethylenediamine tetraacetic acid (Gibco, Paisley, UK), centrifuged for five minutes at $1000 \mathrm{rpm}$ in a bench centrifuge, and resuspended in CDMEM prior to counting in a Neubauer chamber.

\section{BINDING OF A FUMIGATUS SPORES TO A549 \\ CELLS}

A549 cells were seeded in 96-well tissue culture plates (Corning, UK) at $10^{5}$ cells per well and grown overnight to confluence in CDMEM at $37^{\circ} \mathrm{C}$ in an atmosphere of $5 \%$ carbon dioxide in air. Plates were washed once in PBS pH 7.4. The following was adapted from the method of Coulot $e t a l$ for the assessment of spore binding to immobilised proteins.

The spore suspension $(200 \mu \mathrm{l})$ was added to each well and the plates were incubated at $37^{\circ} \mathrm{C}$ in an atmosphere of $5 \%$ carbon dioxide in air for 30 minutes with gentle shaking. Plates were washed three times for five minutes in PBS with $0.05 \%(\mathrm{v} / \mathrm{v})$ Tween 20 . The remaining spores were fixed in $2.5 \%(\mathrm{v} / \mathrm{v})$ glutaraldehyde in PBS for 15 minutes. These spores were counted using a Leitz DM 1L inverted microscope by phase contrast microscopy at $\times 400$ magnification. Five fields of view were counted for each well, in triplicate wells, and the results were expressed as the average number of spores per five high power fields.

\section{BINDING OF SPORES TO A549-DERIVED}

\section{EXTRACELLULAR MATRIX}

A549 cells were seeded and grown overnight as above, then washed once in PBS pH 7.4. Sodium azide at $0.1 \%(\mathrm{w} / \mathrm{v})$ in distilled water was then added $(200 \mu \mathrm{l}$ per well) and the plates were incubated at room temperature for two hours; $4 \%(\mathrm{w} / \mathrm{v})$ deoxycholic acid (sodium deoxycholate) in $0.1 \%(\mathrm{w} / \mathrm{v})$ sodium azide was then added at $200 \mu \mathrm{l}$ per well and the plates were incubated at room temperature for one hour. This was followed by three washes, each of five minutes, in PBS to remove the cells, as verified by light microscopy, leaving a layer of epithelial cell extracellular matrix (ECECM) coated on the plastic as detected by the BioRad protein assay. In the blocking stage bovine serum albumin (BSA, Sigma) was added to both the test wells and the control wells at $1 \mathrm{mg} / \mathrm{ml}$ in PBS (200 $\mu$ l per well) and the plates were incubated at $37^{\circ} \mathrm{C}$ for one hour, then left at $4^{\circ} \mathrm{C}$ overnight, followed by three washes each for five minutes in PBS. Spores of $A$ fumigatus in suspension in PBS were then added as in the above method.

BINDING OF SPORES TO PURIFIED PROTEINS

The following proteins were used: fibrinogen, fibronectin, laminin, type I collagen, and type IV collagen (all from Sigma). The proteins were dissolved according to the maker's instructions (for example, collagen was dissolved in acetic acid) and then coated onto 96-well flatbottomed plates (Greiner) as follows: $200 \mu \mathrm{l}$ protein in PBS pH 7.4 was added to wells at concentrations of $5-500 \mu \mathrm{g} / \mathrm{ml}$. The plates were incubated at $37^{\circ} \mathrm{C}$ for one hour, then washed three times in PBS pH 7.4 for five minutes. Plates were blocked in BSA and spore suspensions added as above, after the method of Coulot et al. ${ }^{7}$

\section{PRETREATMENT WITH INTERFERON $\gamma$}

A549 cells were pretreated in interferon $\gamma$ (IFN$\gamma)$ at $1000-2500$ units per $\mathrm{ml}$ in $\mathrm{PBS}$ at $37^{\circ} \mathrm{C}$ for four hours in an atmosphere of $5 \%$ carbon dioxide in air. IFN- $\gamma$ is known to have an antiproliferative effect on several cell types, ${ }^{8}$ so the number of A549 cells per five fields of view was counted, as well as the number of spores. Results were expressed as the number of adherent spores per 10 cells.

\section{PRETREATMENT WITH HYDROGEN PEROXIDE}

Purified proteins, A549 cells, or ECM components laid down by A549 cells were pretreated with hydrogen peroxide $(2-80 \mu \mathrm{M})$ in PBS at $37^{\circ} \mathrm{C}$ for three hours.

\section{BLOCKING STUDIES}

Spores were pre-incubated with Arg-Gly-Asp tripeptide (RGD; $50-200 \mu \mathrm{g} / \mathrm{ml}$; Sigma) or with the purified proteins mentioned above $(50-500 \mu \mathrm{g} / \mathrm{ml})$ for 15 minutes at $37^{\circ} \mathrm{C}$ in a shaking incubator.

\section{STATISTICAL ANALYSIS}

Results are expressed as the mean (with one standard error) of triplicate wells in experiments carried out 3-5 times. Data were analysed using the Minitab 8.2 package by one way analysis of variance (ANOVA) and Tukey tests for multiple comparisons. Some data for treated spores and proteins were pooled and compared with non-treated controls by one way ANOVA. Where necessary, data were logarithmically transformed to achieve a normal distribution. The effect of treatment was assessed by the variance ratio $(F)$ test. A $p$ value of $<0.05$ was considered significant for all tests. Regression analysis was carried out in some experiments. 


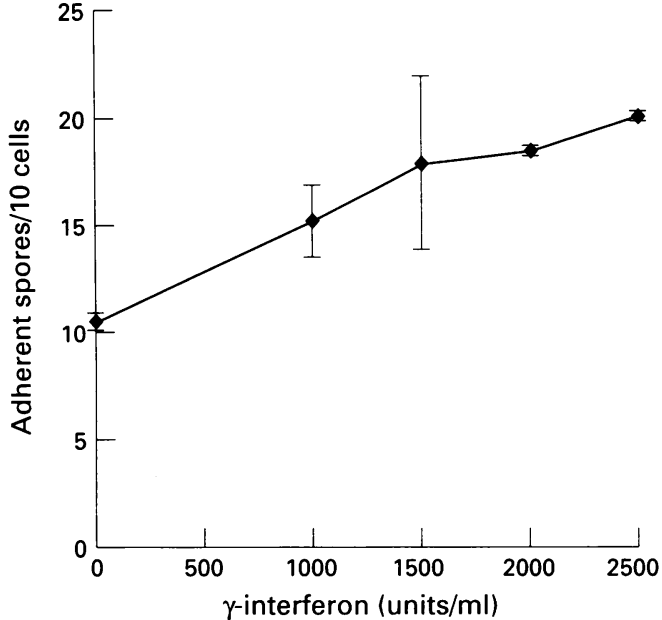

Figure 1 Adherence of $A$ fumigatus spores (at a concentration of $5 \times 10^{6}$ spores $/ \mathrm{ml}$ ) to $A 549$ cell monolayers after pretreatment of cells with gamma interferon (IFN- - ). Results represent mean (SE) spores bound per five high power fields for triplicate wells in three separate experiments and are expressed as the number of adherent spores per 10 cells. Adherence was significantly increased at doses of 1000 units/ml IFN- $\%(p<0.01)$ and above.

\section{Results}

BINDING OF A FUMIGATUS SPORES TO A549

CELLS

Spores of $A$ fumigatus adhered in a concentration dependent manner to A549 cells in vitro (data not shown). Pretreatment of A549 cells with IFN- $\gamma(1000-2500$ units $/ \mathrm{ml})$ caused a significant increase in the number of spores bound per cell at a concentration of 1000 units/ $\mathrm{ml}$ and above $(\mathrm{p}<0.01$ to $\mathrm{p}<0.001$; fig 1$)$ such that approximately twice the number of spores were bound to cells treated with 2500 units/ $\mathrm{ml}$. IFN $-\gamma$ had no significant antiproliferative effect. Pretreatment of A549 cells with 10-80 $\mu \mathrm{M}$ hydrogen peroxide for three hours had no effect on subsequent spore binding (mean (SE) spores bound per five high power fields for triplicate wells in three separate experiments: control 185.6 (21.3); $10 \mu \mathrm{M}$ hydrogen peroxide 162.9 (26.9); $80 \mu \mathrm{M}$ hydrogen peroxide 163.3 (31.4)). Pre-incubation of spores with fibrinogen $(100 \mu \mathrm{g} / \mathrm{ml})$ significantly inhibited adhesion $(\mathrm{p}<0.05)$. However, as is clear from fig 2 , this effect was present only at the two higher spore concentrations where binding was decreased by approximately $30 \%$. The finding of a significant effect across all treatments is a result of the power of the analysis of variance global test. Although PBS incubation was used as a control, fig 3 shows that a control protein (BSA) does not affect binding. The fibrinogen mediated inhibition

Table 1 Spore binding to epithelial cell extracellular matrix (ECECM) or bovine serum albumin (BSA) (1000 $\mu \mathrm{g} / \mathrm{ml})$ after pre-incubation of spores in Arg-Gly-Asp tripeptide (RGD)

\begin{tabular}{|c|c|c|c|c|}
\hline & \multicolumn{4}{|l|}{$R G D(\mu g / m l)$} \\
\hline & 0 & 50 & 100 & 200 \\
\hline $\begin{array}{l}\text { Adherence to ECECM } \\
\text { Adherence to BSA }\end{array}$ & $\begin{array}{c}572.3(70.1) \\
17.4(2.0)\end{array}$ & $\begin{array}{c}570.7(90.7) \\
31.4(6.0)\end{array}$ & $\begin{array}{c}540.1(79.9) \\
28.6(5.6)\end{array}$ & $\begin{array}{l}508.1(63.5) \\
35.9(9.7)\end{array}$ \\
\hline
\end{tabular}

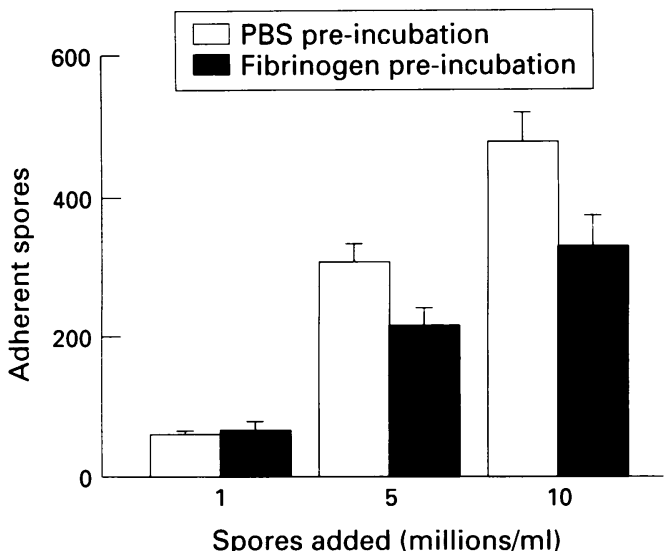

Figure 2 Adherence of $A$ fumigatus spores to $A 549$ cell monolayers after pre-incubation of the spores in fibrinogen $(100 \mu \mathrm{g} / \mathrm{ml})$. Results are mean (SE) spores bound per five high power fields for triplicate wells in five separate experiments. Spores pre-incubated in fibrinogen adhered significantly less avidly $(p<0.05)$ than control spores preincubated in phosphate buffered saline (PBS).

occurred in a dose dependent manner to $50 \%$ inhibition at $500 \mu \mathrm{g} / \mathrm{ml}$ compared with BSA, as shown in fig 3. Analysis of variance showed a significant effect of fibrinogen treatment $(\mathrm{p}<0.001)$.

BINDING OF SPORES TO A549-DERIVED EXTRACELLULAR MATRIX

Spores adhered to ECECM in a concentration dependent manner $(p<0.05)$ and this binding was more than 10 times greater $(p<0.001)$ than adherence to BSA in all experiments (fig 4). Pre-incubation of spores with RGD at concentrations of $50-200 \mu \mathrm{g} / \mathrm{ml}$ had no significant effect on subsequent spore adherence to ECECM (table 1). Pre-incubation of spores in a control protein had no effect (data not shown). Pretreatment of ECECM with

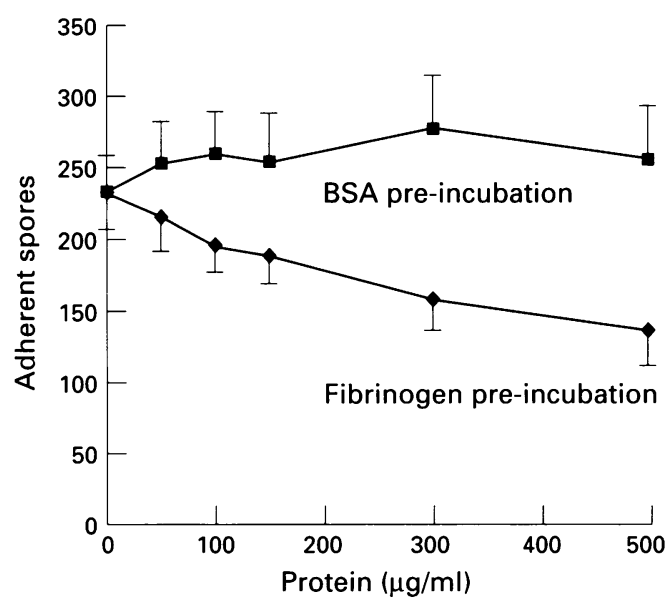

Figure 3 Adherence of $A$ fumigatus spores (at a concentration of $5 \times 10^{6}$ spores $/ \mathrm{ml}$ ) to A549 cell monolayers after pre-incubation of the spores in fibrinogen. Results represent mean (SE) spores bound per five high power fields for triplicate wells in four separate experiments. Pre-incubation of the spores in the control protein bovine serum albumin (BSA) had no effect on adherence. Spores pre-incubated in fibrinogen adhered significantly less avidly than those pre-incubated in $B S A$ $(p<0.001)$. The fibrinogen regression line had a downward slope significantly different from the horizontal $(p<0.001)$. 


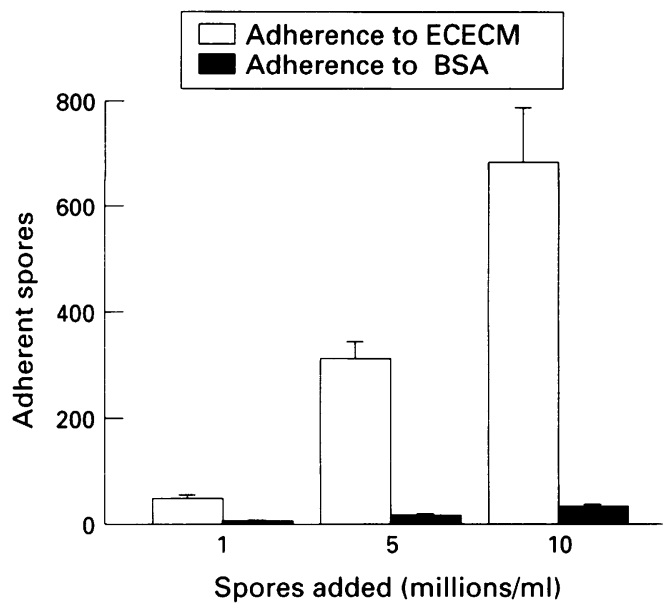

Figure 4 Adherence of $A$ fumigatus spores to epithelial cell extracellular matrix (ECECM). Results represent mean (SE) spores bound per five high power fields for triplicate wells in three separate experiments. Spore binding to ECECM was significantly higher $(p<0.001)$ than adherence to bovine serum albumin (BSA) in all experiments. Binding increased significantly $(p<0.05)$ as the number of added spores increased.

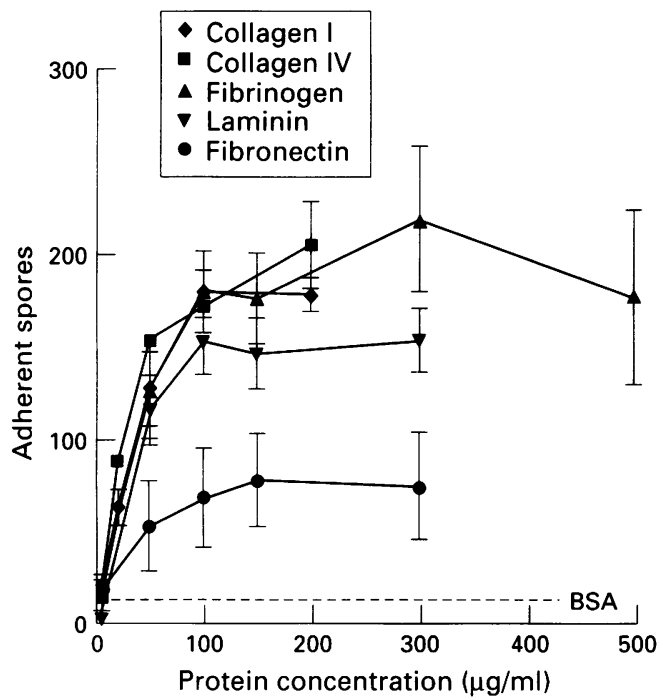

Figure 5 Adherence of $A$ fumigatus spores $\left(10^{6} / \mathrm{ml}\right)$ to proteins at the indicated concentrations. Results are mean (SE) spores bound per five high power fields for triplicate wells in three separate experiments. Spore binding increased significantly ( $p<0.05$ to 0.001$)$ at and above concentrations of $20 \mu \mathrm{g} / \mathrm{ml}$ for type I and type IV collagen, $50 \mu \mathrm{g} / \mathrm{ml}$ for laminin and fibrinogen, and $100 \mu \mathrm{g} / \mathrm{ml} \mathrm{for}$ fibronectin compared with binding to bovine serum albumin (BSA). The dashed line marked BSA shows the minimal spore binding to $B S A(1 \mathrm{mg} / \mathrm{ml})$ and the much greater affinity of the spores for extracellular matrix proteins.

25-80 $\mu \mathrm{M}$ hydrogen peroxide for three hours enhanced spore binding compared with untreated cells. Spores were added at a concentration of $5 \times 10^{6}$ per ml. After one-way ANOVA for different doses there was no significant dose effect of hydrogen peroxide, but when all hydrogen peroxide treatments were taken together they were significantly different from all non-hydrogen peroxide treatments (control, 468.8 (50.9); hydrogen peroxide treated, 643.6 (56.9); $\mathrm{p}<0.01)$. Binding of spores to BSA amounted to about $5 \%$ of binding to ECECM and was not affected by pretreatment with hydrogen peroxide.
BINDING OF SPORES TO PURIFIED PROTEINS

Spore adherence to purified proteins was significantly higher than adherence to BSA in all experiments $(p<0.001)$ - for example, mean (SE) spores bound per five high power fields with fibrinogen $100 \mu \mathrm{g} / \mathrm{ml}$ was 185 (15) compared with 6 (2) with BSA $1000 \mu \mathrm{g} / \mathrm{ml}$. Protein dose responses showed that spore binding increased as the protein concentration increased up to a plateau at $100-150 \mu \mathrm{g} / \mathrm{ml}$ (fig 5) for type I collagen, laminin, fibronectin, and fibrinogen; in the case of type IV collagen the curve had not quite levelled out at the highest concentration $(200 \mu \mathrm{g} / \mathrm{ml})$. Spore binding to BSA coated wells $(1000 \mu \mathrm{g} / \mathrm{ml})$ was minimal, as shown by the dashed line in fig 5 , and this demonstrates the greater affinity of the spores for ECM proteins.

Protein concentrations on the plateau were chosen for subsequent experiments $(200 \mu \mathrm{g} / \mathrm{ml}$ for type IV collagen) in which spores adhered to purified proteins in a spore number dependent manner (data not shown). There was no significant difference in avidity for different proteins. Pre-incubation of spores with RGD had no effect on binding to fibrinogen, laminin, or type IV collagen. Spore binding to fibronectin $(p<0.01)$ and type I collagen $(p<0.001)$, however, was significantly decreased, by more than $50 \%$ after RGD pre-incubation (fig 6). Pretreatment of proteins with hydrogen peroxide $(0-80 \mu \mathrm{M})$ had no effect on spore adherence (data not shown).

COMPARISON OF SPORE BINDING TO CELLS AND PROTEINS

Figure 7 was composed to give an indication of the range of avidity of spores for different surfaces likely to be found in normal and asthmatic lungs. Spores were found to have increasing avidity as follows: BSA (control protein) $(1000 \mu \mathrm{g} / \mathrm{ml})<\mathrm{A} 549$ cells (confluent) < ECECM (from confluent A549 cells) $<$ IFN- $\gamma$ activated A549 cells (confluent) < purified ECM proteins (average of fibronectin $(150 \mu \mathrm{g} / \mathrm{ml})$, laminin, type I collagen, and type IV collagen (all $100 \mu \mathrm{g} / \mathrm{ml}$ )).

\section{Discussion}

This study was undertaken to determine whether asthmatic lungs are more liable than normal lungs to allow the spores of Aspergillus fumigatus to attach and persist. The asthmatic lung has activated epithelial cells, ${ }^{9}$ exposed basement membrane resulting from epithelial detachment, ${ }^{1011}$ and is under oxidant stress from inflammatory cells. ${ }^{1213}$ The experiments described here set out to mimic these conditions in vitro to quantify $A$ fumigatus spore binding in these circumstances.

Adherence to host epithelium is one of the crucial steps in the pathogenesis of infectious micro-organisms. We have demonstrated for the first time, to our knowledge, the ability of spores of $A$ fumigatus to adhere preferentially to A549 human lung epithelial cells in vitro compared with a control protein. Binding of $A$ fumigatus spores to human type II alveolar 


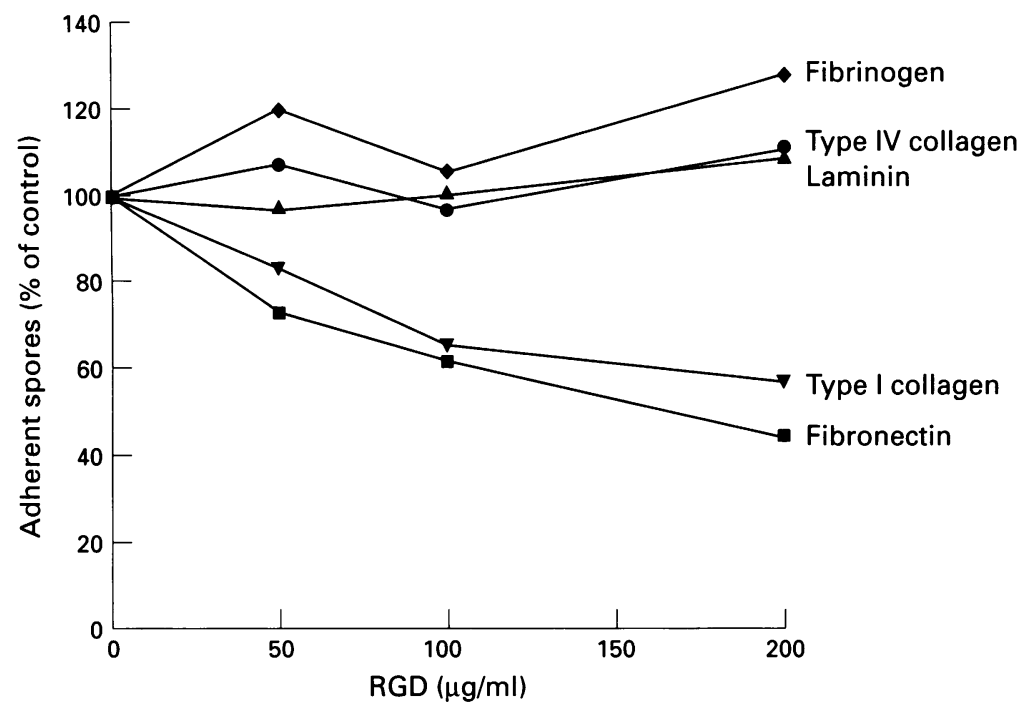

Figure 6 Binding of A fumigatus spores $\left(10^{6} / \mathrm{ml}\right)$ to proteins in a concentration of $100 \mu \mathrm{g} / \mathrm{ml}$ (except fibronectin $150 \mu \mathrm{g} / \mathrm{ml}$ ) after pre-incubation with Arg-Gly-Asp tripeptide (RGD) at the indicated concentrations. Results are expressed as mean spores bound per five high power fields for triplicate wells in three separate experiments expressed as a percentage of the values for control spores pre-incubated in phosphate buffered saline (PBS). The standard errors were between one twentieth and one third of mean values. Pre-incubation of spores in RGD had no effect on adherence to bovine serum albumin (BSA), fibrinogen, laminin, or type IV collagen, but it inhibited spore binding to fibronectin $(p<0.01)$ and type I collagen $(p<0.001)$. Spore adherence to purified proteins was significantly higher than adherence to $B S A(1000 \mu \mathrm{g} / \mathrm{ml})$ in all experiments $(p<0.001)$.

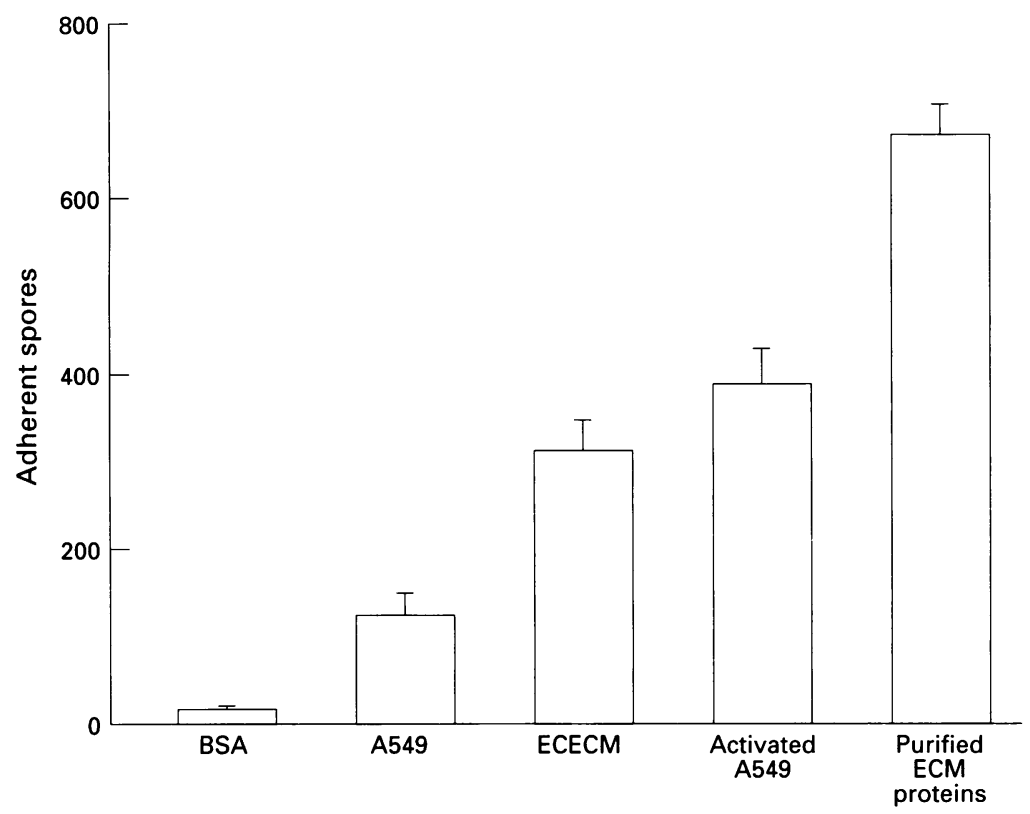

Figure 7 Comparison of levels of spore binding to different proteins and cells. Results represent mean (SE) spores bound per five high power fields for triplicate wells in three separate experiments. Activated A549 cells were pretreated with interferon gamma (2500 units $/ \mathrm{ml}$ ). Purified extracellular matrix (ECM) proteins represent the mean values for fibronectin, laminin, type I collagen, and type IV collagen. Spores were added at a concentration of $5 \times 10^{6} \mathrm{per} \mathrm{ml}$. BSA=bovine serum albumin; ECECM=epithelial cell extracellular matrix cells more effectively. Spores of $A$ fumigatus have been shown to produce a diffusible toxin that decreases lung macrophage spreading, respiratory burst, and cytokine production, ${ }^{17-19}$ and also inhibits epithelial cell spreading. ${ }^{20}$ Spores that are attached to epithelial cells, as demonstrated here, would be able to deliver the spore toxin in a more concentrated form, so enhancing its adverse effects. Disruption of the integrity of the epithelial lining could then allow access to the underlying basement membrane and interstitial proteins.

There is evidence of $T$ cell immunity in asthma ${ }^{21}$ with accompanying upregulation of intercellular adhesion molecule 1 (ICAM-1) and other cell surface molecules via cytokines and other mediators of inflammation. ${ }^{9223}$ In an animal model of allergic bronchopulmonary aspergillosis ICAM-1 expression on epithelial cells is enhanced. ${ }^{24}$ IFN- $\gamma$ activates epithelial membrane ICAM-1 and MHC class II antigen. ${ }^{25} 26$ In the present study epithelial cell activation with IFN- $\gamma$ resulted in a marked increase in spore binding and we conclude that the activated epithelium in asthma may be one of the predisposing factors to $A$ fumigatus attachment and colonisation. The putative role of ICAM-1 in the adherence of spores to epithelial cells will be investigated in future work.

Inflammation is present in the asthmatic lung ${ }^{2728}$ and there is evidence of increased levels of reactive oxygen species released by eosinophils, neutrophils, and macrophages. ${ }^{1213}$ However, treatment of the epithelium with hydrogen peroxide before exposure to the spores had no effect on spore adhesion.

Spores of $A$ fumigatus bind to fibrinogen ${ }^{29}$ so we pre-incubated the spores in fibrinogen which inhibited adhesion; incubation in a control protein had no effect. Since fibrinogen specifically blocked binding sites on the spore, we suggest that the cell membrane ligand for spores resembles fibrinogen. Fibrinogen is found in larger quantities in the lungs of asthmatic patients than in normal lungs, ${ }^{3031}$ so the presence of fibrinogen in the lung air space could be beneficial to the asthmatic host by inhibiting the adhesion of $A$ fumigatus spores.

We used the cells of an alveolar epithelial cell line (A549) in the present study as a model air space epithelial cell. However, we recognise that the epithelial cell type of most direct relevance to asthma is the airway epithelial cell which may differ from alveolar epithelial cells in terms of the responses to spores and to the treatments used here.

Epithelial cells in culture synthesise and secrete ECM glycoproteins including type IV and $\mathrm{V}$ collagens, fibronectin, and laminin. In asthma the epithelial lining cells are shed, exposing the underlying basement membrane, ${ }^{1011}$ and this detachment may result from the action of proteases and oxidants released by local activated leucocytes. ${ }^{32-34}$ Oxidants such as hydrogen peroxide increase epithelial permeability and decrease cell proliferation, ${ }^{35}$ which could allow pathogens access to denuded areas for a long period of time due to slow repair. 
In the present study $A$ fumigatus spores were able to adhere to ECECM components laid down by A549 epithelial cells which was consistently far higher than binding to the control protein BSA. The ability of $A$ fumigatus spores to adhere to the basement membrane may confer a further advantage in the asthmatic lung environment.

The RGD tripeptide, which is involved in cell adhesion, was found not to play a part in the binding of spores to ECECM in blocking studies. This may be a result of the complex nature of the ECECM compared with simple purified proteins, or to the process of preparing the ECECM. Pretreatment of the ECECM with hydrogen peroxide to mimic oxidant stress to the ECM that might occur in the asthmatic lung enhanced spore binding, indicating that oxidant stress is an additional factor in spore persistence.

Spores of $A$ fumigatus are able to adhere to fibrinogen via a proteinaceous receptor that is not present on hyphae, ${ }^{7}$ and have been reported to bind to laminin. ${ }^{36}$ In our experiments $A$ fumigatus spores adhered to fibrinogen, fibronectin, laminin, type I collagen, and type IV collagen in much greater numbers than to a control protein. Binding of spores to ECM proteins indicates that components of the basement membrane could be the targets for spore binding. Spore adherence to basement membrane proteins was found to be greater than adherence to epithelial cells, indicating increased avidity of spores for epithelium damaged lung. Binding to fibrinogen indicates that spores may be able to adhere to fibrin deposits in the inflamed lung. Pre-incubation of spores with RGD inhibited binding to fibronectin and type I collagen and this suggests that the spores bind to an RGD sequence on these proteins. Since RGD is not available on native collagen but is revealed on denatured collagen, ${ }^{37}$ our data suggest that there is a degree of denaturation in the type I collagen as supplied. The mycelium of Candida albicans has been reported to possess an integrin-like receptor ${ }^{38}$ and the $A$ fumigatus spores may also have such a molecule on their surface. Candida albicans also adheres to type I and type IV collagens, fibronectin, and laminin; this is inhibited by fragments of denatured collagen (gelatin) via blockage of fungal adhesins. ${ }^{39}$ Some pathogenic bacteria also bind to a known site on laminin by mimicking a host epithelial cell receptor. ${ }^{40}$

Figure 7 compares spore binding to different surfaces present in normal and asthmatic lungs. We showed that spores of $A$ fumigatus did not have the same avidity for all the surfaces investigated. Binding of spores to surfaces was as follows: purified ECM proteins>activated A549 cells $>$ ECECM $>$ A549 cells $>$ BSA (control protein). These data suggest that the asthmatic lung is an environment that is likely to be more conducive to the adherence and persistence of $A$ fumigatus spores than the normal lung. However, fibrinogen may be an important defensive mechanism for protecting the asthmatic lung against $A$ fumigatus spores.

1 Bateman ED. A new look at the natural history of Aspergillus hypersensitivity in asthmatics. Respir Med 1994;88:325-7.
2 Wagner GE. Bronchopulmonary aspergillosis and aspergilloma. In: Al-Doory Y, Domson JF, eds. Mould allergy. gilloma. In: Al-Doory Y, Domson JF, eds. Mould

3 Mullins J, Seaton A. Fungal spores in lung and sputum. Clin Allergy 1978;8:525-33.

4 Kauffman HF, Tomee JFC, van der Werf TS, de Monchy JGR, Koeter GK. Review of fungus-induced asthmatic reactions. Am F Respir Crit Care Med 1995;151:2109-16.

5 Hendrick DJ, Davies RJ, D'Souza MF, Pepys J. An analysis of skin prick test reactions in 656 asthmatic patients. Thorax 1975;30:2-8.

6 Pepys J, Riddel RW, Citron KM, Clayton YM, Short EI Clinical and immunologic significance of Aspergillus fuClinical and immunologic significance of Aspergillus fu-
migatus in the sputum. Am Rev Respir Dis 1959;80:167-80.

7 migatus in the sputum. Am Rev Respir Dis 1959;80:167-80. $\mathrm{C}$, Tronchin G, et al. Specific interaction of Aspergillus fumigatus with fibrinogen and its role in cell adhesion. Infect Immun 1994;62:2169-77.

8 Baron S, Tyring SK, Fleischmann WR, Coppenhaver DH, Niesel DW, Klimpel GR, et al. The interferons. Mechanisms of action and clinical implications. F $A M A 1991$ 266: $1375-83$.

9 Vignola AM, Campbell AM, Chanez P, Bousquet J, PaulLacoste P, Michel F-B, et al. HLA-DR and ICAM-1 expression on bronchial epithelial cells in asthma and chronic bronchitis. Am Rev Respir Dis 1993;148:689-94

10 Jeffery PK, Wardlaw AJ, Nelson FC, Collins JV, Kay AB. Bronchial biopsies in asthma: an ultrastructural, quantitative study and correlation with hyperreactivity. Am Rev Respir Dis 1989;140:1745-53.

11 Laitinen LA, Heino M, Laitinen A, Kara T, Haahtela T Damage of the airway epithelium and bronchial reactivity in patients with asthma. Am Rev Respir Dis 1985;131: 599-606.

12 Cluzel M, Damon M, Chanez P, Bousquet J, Crastes de Paulet A, Michel FB, et al. Enhanced alveolar cell luminoldependent chemiluminescence in asthma. $f$ Allergy Clin Immunol 1987;80:195-201.

13 Kelly C, Ward C, Stenton CS, Bird G, Hendrick DJ, Walters EH. Number and activity of inflammatory cells in bronchoalveolar lavage fluid in asthma and their relation in bronchoalveolar lavage fluid in asthma and their

14 Thau N, Monod M, Crestani B, Rolland C, Tronchin G, Latge J-P, et al. Rodletless mutants of Aspergillus fumigatus. Infect Immun 1994;62:4380-8.

15 Angioi A, Zanetti S, Sanna A, Delogu G, Fadda G. Adhesiveness of Bacillus subtilis strains to epithelial cells cultured in vitro. Microb Ecol Health Dis 1995;8:71-7.

16 Pottratz ST, Weir AL, Wisniowski PE. Pneumocystis carini attachment increases expression of fibronectin-binding integrins on cultured lung cells. Infect Immun 1994;62 5464-9.

17 Robertson MD, Seaton A, Milne LJR, Raeburn JA. Resistance of spores of Aspergillus fumigatus to ingestion by sistance of spores of Aspergillus fumigatus
phagocytic cells. Thorax 1987;42:466-72.

18 Slight J, Nicholson WJ, Mitchell CG, Pouilly N, Beswick $\mathrm{PH}$, Seaton $\mathrm{A}$, et al. Inhibition of the alveolar macrophage oxidative burst by a diffusible component from the surface of the spores of the fungus Aspergillus fumigatus. Thorax 1996;51:389-96.

19 Nicholson WJ, Slight J, Donaldson K. Inhibition of the transcription factors NFKB and AP-1 underlies the loss of cytokine gene expression in rat alveolar macrophages treated with a diffusible product from the spores of Aspergillus fumigatus. Am $\mathcal{f}$ Respir Cell Mol Biol 1996; 15: 88-96.

20 Nicholson WJ, Beswick PH, Bromley IMJ, Donaldson K, Mitchell CG, Pouilly N, et al. Characterisation of the biological activity and size of toxin(s) obtained from the surface of the spores of Aspergillus fumigatus. Am $\mathcal{F}$ Respir surface of the spores of Aspergillus
Crit Care Med 1995;151:A245.

21 Walker C, Virchow JC, Bruijnzeel PLB, Blaser K. T cell subsets and their soluble products regulate eosinophilia in allergic and non-allergic asthma. F Immunol 1991;146 1829-35.

22 Gelder CM, Thomas PS, Yates DH, Adcock IM, Morrison JFJ, Barnes PJ. Cytokine expression in normal, atopic and asthmatic subjects using the combination of sputum induction and the polymerase chain reaction. Thorax 1995 50:1033-7.

23 Vignola AM, Campbell AM, Chanez P, Lacoste P, Michel FB, Godard P, et al. Activation by histamine of bronchial epithelial cells from nonasthmatic subjects. Am $\mathcal{J}$ Respir Cell Mol Biol 1993;9:411-7.

24 Chu HW, Wang JM, Boutet M, Boulet L-P, Laviolette $M$. Increased expression of intercellular adhesion molecule-1 (ICAM-1) in a murine model of pulmonary eosinophilia (ICAM-1) in a murine model of pulmonary eosinophilia

25 Rothlein R, Czajkowski M, O'Neill MM, Marlin SD, Mainolfi E, Merluzzi VJ. Induction of intercellular adhesion molecule-1 on primary and continuous cell lines by proinflammatory cytokines. Regulation by pharmacologic agents and neutralising antibodies. F Immunol 1988;141 $1665-9$.

26 Suda T, Sato A, Sugiura W, Chida K. Induction of MHC class II antigens on rat bronchial epithelial cells by interferon-gamma and its effect on antigen presentation. Lung 1995;173:127-37.

27 Beasley R, Roche WR, Roberts JA, Holgate ST. Cellular events in the bronchi in mild asthma and after bronchial provocation. Am Rev Respir Dis 1988;139:806-17.

28 Smith DL, Deshazo RD. Bronchoalveolar lavage in asthma an update and perspective. Am Rev Respir Dis 1993;148: 523-32.

29 Annaix V, Bouchara JP, Larcher G, Chabasse D, Tronchin $G$. Specific binding of human fibrinogen fragment $D$ 
to Aspergillus fumigatus conidia. Infect Immun 1992;60: $1747-55$.

30 Salomonsson P, Groenneber $R$, Gilliam $H$, Andersson $O$ Billing B, Enander I, et al. Bronchial exudation of bulk plasma at allergen challenge in allergic asthma. $A m R e v$ Respir Dis 1992;146:1535-42.

31 Fahy JV, Liu J, Wong H, Boushey HA. Cellular and biochemical analysis of induced sputum from asthmatic and from healthy subjects. Am Rev Respir Dis 1993;147:112631.

32 Venaille TJ, Mendis AHW, Phillips MJ, Thompson PJ, Robinson BWS. Role of neutrophils in mediating human epithelial cell detachment from native basement membrane. F Allergy Clin Immunol 1995;95:597-605.

33 Donaldson K, Slight J, Brown GM, Bolton RE. The ability of inflammatory bronchoalveolar leucocyte populations licited with microbes or mineral dust

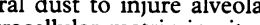
Br f Exp Pathol 1988;69:327-38.

34 Yukawa T, Read RC, Kroel $C$.

$K$, Wilson $\mathrm{R}$, Futman A, Fan Chun , Wilson R, et al. The effects of activated eosinophils and neutrophils on guinea pig airway epithelium in vitro.
35 Yamaya M, Sekizawa K, Masuda T, Morikawa M, Sawai $\mathrm{T}$, Sasaki $\mathrm{H}$. Oxidants affect permeability and repair of he cultured human tracheal epithelium. Am $\mathcal{f}$ Physiol Lung Cell Mol Physiol 12 1995;268:L284-93.

36 Tronchin G, Bouchara JP, Larcher G, Lissitzky JC, Chabasse $D$. Interaction between Aspergillus fumigatus and basement Biol Cell 1993;77:201-8.

37 Yamamoto $M$, Yamato $M$, Aoyagi $M$, Yamamoto $K$. Identification of integrins involved in cell adhesion to native and denatured type I collagens and the phenotypic transition of rabbit arterial smooth muscle cells. Exp Cell Res 1995; rabbit arterial

38 Santoni G, Gismondi A, Liu JH, Punturieri A, Santoni A Frati L, et al. Candida albicans expresses a fibronectin receptor antigenically related to alpha-5-beta-1 integrin. Microbiology 1994;140:2971-9.

39 Klotz SA, Smith RL. Gelatin fragments block adherence of Candida albicans to extracellular matrix proteins. Microbiology 1995;141:2681-4.

40 Martin GR, Timpl R. Laminin and other basement membrane components. Ann Rev Cell Biol 1987;3:57-85. 